\title{
Marketing Around

\section{The Development of Marketing in the Netherlands}

Within the field of business economics in the Netherlands there was a tradition that can be characterized as an institutional and functional approach to marketing. The focus was on institutions such as wholesaling, retailing, auctions, futures markets, etc. and on the marketing functions performed by the various institutions and firms, with special attention for the commercial firm and its contribution to the distribution process. Examples of this are found in Haccoû (1948) and Van Muiswinkel (1957, 1959). This approach is quite different from today's view of marketing: marketing management as decision making by the firm with respect to the instruments of the marketing mix, important for the manufacturing as well as the commercial firm. In the Netherlands the advent of the latter type of marketing was preceded by the development of market research. The increasing attention for market research since 1945 undoubtedly stimulated this interest in marketing. Immediately after World War II three pioneering market research firms were founded: IHO (now SOCMAR: Social and Marketing Research), NSS (v/h Nederlandse Stichting voor Statistiek), and NIPO (Nederlands Instituut voor het Onderzoek van de Publieke Opinie). Among the current number of about 60 market research firms, the three pioneering firms still hold a very prominent position.

One of the first introductory books in market research in the Netherlands is Van Rees (1946). In 1950 the first edition of Verdoorn's Grondslagen en Techniek van de Marktanalyse (Fundamentals and Techniques of Market Research) was published. This book remained a classic in the Dutch market research community until the late seventies. There was also an American-Dutch collaboration, Ferber and Verdoorn (1962), Research Methods in Economics and Business.
The development of market research in the Netherlands has been described by Van der Zwan (1975) in three phases: pioneering phase, 1946-1960; expansion, 1960-1970; stabilization, 1970-... With a time lag of about five years, the same can probably be said about marketing. Although marketing practice may have been around for a long time, marketing management as a deliberate guiding concept for business decisions only started to receive widespread attention in the fifties. During the sixties, more and more firms set up marketing departments and applied the analysis-planning-control paradigm of marketing in their decision making.

Probably not unlike the diffusion process of marketing in other countries, consumer goods firms were the first to adopt the marketing concept in the Netherlands. The firms in industrial products followed later, and at present progress in marketing can be observed in service industries like banking, insurance, and recreation. The interest in marketing is also growing quickly in the nonprofit sector.

In 1966 NIMA (Nederlands Instituut voor Marketing), the professional organization for marketing in the Netherlands, was founded. Its aims are the implementation of marketing in the management of business firms, nonprofit and government organizations, and improvement in the level of marketing know-how and marketing practice. Currently, NIMA has about 1300 members in 450 firms and organizations. There are also several private members: consultants and personnel from universities and other educational institutions. After having done much to get the marketing concept accepted, the emphasis of NIMA is now on furthering professional interests, the organization of seminars and conferences of actual topics, educational activities, the study of important developments for marketing (e.g., consumerism), etc.

The market research community has its own professional organization founded in 1963, the NVM (Nederlandse Vereniging van Marktonderzoekers). 
Currently, the NVM has about 600 members, roughly one-third of them coming from market research agencies. There are historical reasons for the existence of two separate professional organizations in the field of marketing and market research. Integration of both organizations, which have considerable overlap in their areas of interest, might be beneficial for the Dutch marketing and market research community.

The advent of marketing brought about a demand for marketing education. Most of the academic marketing groups now existing were established in the second half of the sixties and the early seventies. Only Professor Verdoorn at Erasmus University started teaching "commercial economics" around 1960.

Marketing has traditionally evolved from economics. More recently, interdisciplinary institutions of the business school type have been established. Examples of these are the Nijenrode Institute of Business Studies (undergraduate) and the Graduate School of Management (Delft). At first, the academic marketing groups were preoccupied with organizing teaching. Now that they are established, research is getting more attention, and a steady stream of papers, articles, and books is being produced (see next section). Marketing education started at the university level. At present, marketing is one of the major subjects in many other types of schools, especially higher vocational colleges.

\section{Marketing Publications}

\section{Sources}

In this article we restrict ourselves to academic publications. All academic marketing groups were asked to produce a list of their publications over the period 1977-80. Thanks to the cooperation of my colleagues, the response in this (mail) survey was very high.' Because of space limitations, marketing publications from authors outside the universities are not discussed here. During 1977-80, 112 such articles appeared in Tijdschrift voor Marketing, the official monthly publication of the NIMA, and 40 articles in Jaarboek van de Nederlandse Vereniging voor Marktonderzoekers, the annual publication of the Association of Market Researchers (NVM). More detailed information about publication activities in The Netherlands, also dealing with publications from nonacademic sources, can be found in Wierenga (1981).

'Only the Municipal University of Amsterdam, where because of the small size of the marketing group the research possibilities are very limited, did not respond.

\section{Publications from Academic Institutions}

The total number of publications over the period $1977-80$ listed by the responding marketing groups is $230{ }^{2}$ The number of (academic) authors is 42 . (In some cases there is an external coauthor.) The largest number of contributors (each with $20 \%$ or more) are from Rotterdam and Groningen, followed by Tilburg and Wageningen with $16 \%$ and $14 \%$ respectively. All other institutions have less than $10 \%$ share in the overall publication activity. With respect to Tilburg, the majority of the publications (i.e., 33) are not from the marketing group but from the Department of Economic Psychology where a great deal of research in consumer behavior is done.

\section{Types of Publication}

Dutch marketing periodicals, other national journals (e.g., in the fields of economics and business administration) and national conference papers together constitute $44 \%$ of all publications. Nevertheless, $24 \%$ of all publications refer to articles and papers in international journals and for international conferences. Of the papers presented at international conferences, the largest number (10) are those presented at meetings of the European Academy for Advanced Research in Marketing (EAARM), seven were presented at the Annual Colloquium of European Psychologists, and six were presented at conferences organized by the European Market Research Society, ESOMAR. This relatively strong international orientation of marketing research activities in the Netherlands is also reflected by one-third of all publications (73 of the 230) being published in English (all the others are in Dutch). Within the European Academy for Advanced Research in Marketing, the Netherlands with $17 \%$ of the membership is the largest national group.

The ten books' share in total publication activities is much larger than their number would indicate. Four works are dissertations whose subjects are information processing and consumer choice (Van Raaij 1977), price sensitivity in the use of electricity (Van Helden 1978), consumer and information, the role of comparative product testing (Box 1979), and export marketing (Bakker 1980). (The first is in English.) The comprehensive work on market research and its techniques (Van der Zwan and Verhulp 1980) should also be mentioned. It is a modern follow-up of Verdoorn (1950) mentioned earlier. Also, one of the books is a Belgian-Dutch collabora-

\footnotetext{
${ }^{2}$ The complete list of authors and titles is available from the author upon request.
} 


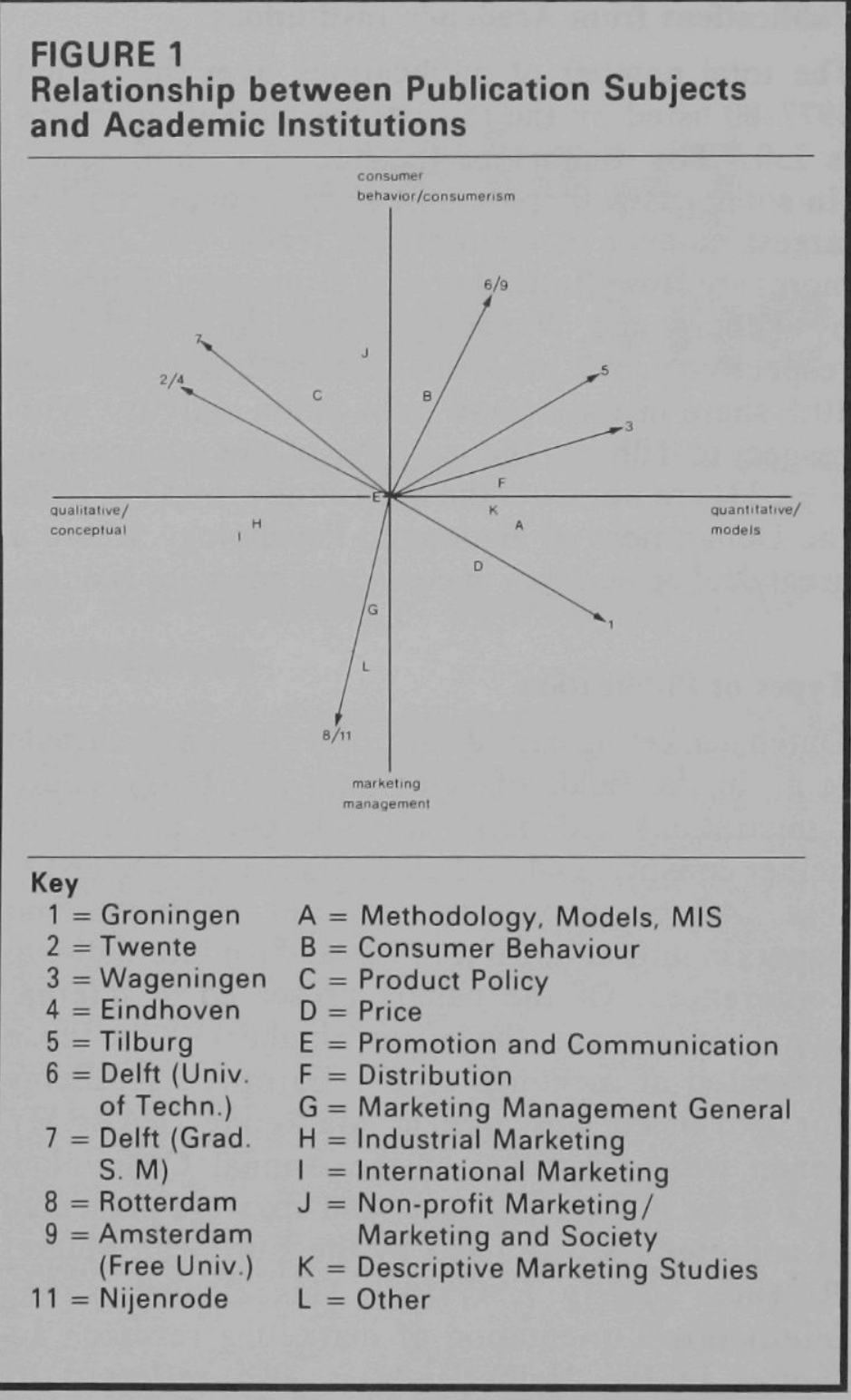

tion, Building Implementable Marketing Models by Naert and Leeflang (1978).

\section{Subject Areas}

The two single largest categories are research methodology/models and consumer behavior. Dutch efforts in research in marketing resemble those of the U.S. as reported by Myers et al. (1979, p. 27). However, marketing management also gets a substantial share: There are 66 items on specific marketing mix elements and marketing management in general. The relatively large number of papers in the area of nonprofit marketing and societal marketing is probably due to the relatively large public sector in the Dutch economy. Also, since The Netherlands is a densely populated country, problems of environmental effects of industrial production, air and water pollution, etc., are felt earlier than in a more sparsely populated country. Finally, it is obvious that in a country with an open economy like the Netherlands, export and international marketing receive considerable attention.

\section{Academic Institutions and Publication Subjects}

There is a certain amount of specialization in the research of the different academic institutions. The institutions focus on various subjects as shown in Figure $1 .^{3}$ The vectors labelled by the numbers 1 , 2 , etc. represent academic institutions. The letters A, B, C, etc. refer to subject areas (points in the two-dimensional space). The results suggest that the subject area with the highest overall frequency, research methodology/models (A) received a lot of attention in the publications from Groningen (1), Wageningen (3), and Tilburg (5). Another important area, consumer behavior (B) constitutes a relatively large proportion of the publications from Tilburg (5), Wageningen (3), and Delft (6)/Amsterdam (9). The latter institutions put still more emphasis on nonprofit marketing and consumerism (J). The Graduate School of Management (Delft) and the University of Eindhoven (here fused with Twente) combine publications in the area of nonprofit marketing with international (I) and industrial marketing (H). The Erasmus University (combined with Nijenrode) places a lot of emphasis on general marketing management. From the location of promotion and communication (E) close to the origin, it is clear that so far no university shows a notable dominance of this subjqct area in its publications. The axes in Figure 1 can be tentatively labelled as quantitative/conceptual and quantitative/models (horizontal axis), and consumer behavior/consumerism versus marketing management (vertical axis).

The different orientation of the various marketing groups are not the result of some kind of comprehensive master plan. In some instances the research direction can partly be explained by the type of institution: A university of technology generally places a great deal of emphasis on industrial products and an agricultural university on fast-moving consumer goods. However, the interests, training, and background of the researchers also play a role in the choice of the type of work. This implies that the picture is not static. Over the period 1981-84 the scene may well be different from that of 1977-80. There is some mutual consultation about research matters among the different universities through the Scientific Committee of the NIMA.

\footnotetext{
${ }^{3}$ Figure 1 results from a MDPREF-analysis of an institutions-bysubjects matrix.
} 


\section{Conclusions and Expectations}

Although there may be differences regarding the pace of development and specific orientations, in general there are no fundamental differences between marketing in the Netherlands and marketing in other western countries like the U.S. and the U.K. This is true for both marketing management and marketing research. Of course the whole field is younger here and especially with respect to research, further growth seems to be possible and likely. Some phenomena seem to be especially cross cultural. One example is the continuing discussion about the relevance of research in marketing for marketing practice. See also Myers et al. (1979, p. 17). Also, in the Netherlands the academic and the business marketing people can be clearly distinguished. There are many efforts to narrow the gap using seminars, post-academic courses for marketing executives, review articles about new developments, consulting activities by academics, and practical work by university students in businesses. Nevertheless, it is still very true that not all analytical models developed by researchers are used in practice.

What are the expectations for marketing in the Netherlands in the future? Based on trends now visible, the following expectations can be (speculatively) expressed.

- A further penetration will be observed in the use of marketing, especially in the areas of industrial marketing, marketing of services, nonprofit and government marketing.

- A lot of attention will be paid to the constraints of marketing: consumerism, environmental consequences, shortages of raw materials, societal aspects, ethics of marketing. The topic of a recent NIMA conference was "Marketing in narrow waters."

- Marketing will become an established business function and will lose something of its "new" or "dynamic" appeal of the earlier days. More emphasis will be placed on the interdependence between marketing and other functions: production, $R \& D$, finance, selling, etc. There is also a growing interest in strategic market planning.

- As a consequence of the trend in Dutch society towards more planning and coordination among firms at industry and national levels, marketing at a higher level than the individual firm (macromarketing?) will increase and become a problem area.

- Because of the increasing influence of con- sumers and their organizations there will be a continuing research emphasis on consumer behavior and consumer affairs. Recently a special research institute, S.W.O.K.A., ${ }^{4}$ was founded for this purpose. This institute, directed by consumers' organizations and the government, is to carry out research in all areas of consumer affairs, primarily from a consumer policy point of view.

- Methodology and quantitative models will remain an important area of research. In many firms, marketing information systems are emerging which constitute a positive factor for the use of analytical marketing models in business decisions.

- Finally, because of the large nonprofit sector in the Dutch economy and the increasing recognition of the impact of business decisions on society as a whole, an important part of the research efforts in marketing will be dedicated to nonprofit marketing and societal aspects of marketing.

Berend Wierenga

Department of Marketing and

Marketing Research

Wageningen Agricultural University

The Netherlands

\section{REFERENCES}

Bakker, B. A. (1980), Export en Marketing; enige aspecten van exportmarketing en exportsamenwerking bij Nederlandse ondernemingen, Samson, Alphen aan de Rijn.

Box, J. M. F. (1979), Konsument en Informatie; de rol van vergelijkend warenonderzoek, Delft: Delftse Universitaire Pers, 338.

Ferber, R. and P. J. Verdoorn (1962), Research Methods in Economics and Business, New York: MacMillan, 573.

Haccoû, J. F. (1948), Handel en Martkwezen in Goederen, I en II, Leiden: Stenfert Kroese, first edition.

Myers, J. G., S. A. Greyser, and W. F. Massy (1979), "The Effectiveness of Marketing's 'R\&D' for Marketing Management: An Assessment," Journal of Marketing, 43 (January), 17-29.

Naert, P. A. and P. S. H. Leeflang (1978), Building Implementable Marketing Models, Leiden: Martinus Nijhoff, 406.

Van der Zwan, A. (1975), "Haalt het marktonderzoek 1984? Een analyse van de ontwikkelingsgang en stand van zaken," Jaarboek NVM, 3-47.

, and J. Verhulp (1980), Grondslagen en Techniek van de Maktanalyse, Leiden: Stenfert Kroese, 792.

Van Helden, G. J. (1978), De Prijsgevoeligheid van het

\footnotetext{
${ }^{4}$ Stichting Wetenschappelijk Onderzoek Konsumenten Aangelegenheden.
} 
Huishoudelijke Electriciteitsverbruik, Leiden: Stenfert Kroese.

Van Muiswinkel, F. L. (1957), Handel, Markt en Beurs, Amsterdam: Noord-Hollandse Uitgeversmaatschappij, first edition.

(1959), De Handelsonderneming, Amsterdam: Noord-Hollandse Uitgeversmaatschappij.

Van Raaij, W. F. (1977), Consumer Choice Behavior: An Information-Processing Approach, Tilburg: Catholic University.

Van Rees, J. (1946), Inleiding tot het Marktonderzoek, Wassenaar: N. V. Uitgeversmaatschappij v/h Delwel.

Verdoorn, P. J. (1950), Grondslagen en Techniek van de Marktanalyse, Leiden: Stenfert Kroese.

Wierenga, B. (1981), "Underzoek in Marketing in Nederland," Tijdschrift voor Marketing (December).

\section{Marketing in Norway}

This article gives a brief characterization of mainstreams of Norwegian research in marketing, distribution, and consumer behavior. Marketing research is relatively new in Norway, and more publications have appeared in the last 10 years than in its entire earlier history. This review is limited to research publications appearing in 1978 or later. Articles available in the primary international (English) journals are not included, and for obvious reasons my own work is excluded. Earlier reviews of parts of the research output may be found in Gripsrud (1978b) and Grønhaug (1978a).

It is argued here that the political-economic environment determines marketing practices, which in turn influence marketing research. Hence, a few words on the setting for marketing research are needed.

\section{The Context of Marketing Research}

As compared with the United States, Norway is small (population is slightly above four million), ethnically and culturally homogeneous, fairly affluent (high average incomes, more equal distribution of income and wealth), media poor (no commercial TV or radio stations), dominated by small business, and is a highly regulated, cradle-to-gravewelfare society. In addition, Norway is very dependent on foreign trade (exports plus imports are higher than the net domestic product), though the country is more than self-sufficient in energy thanks to the North Sea oil resources.

On the small, homogeneous, and often very transparent markets for most consumer goods, traditional market segmentation strategies are often inappropriate. Instead, many manufacturers resort to various "push" strategies, mostly special deals and discounts to the trade. Export marketing has been given high political priority.

Marketing is being taught only in one graduate school of business plus several two-year regional colleges and in a couple of private schools of management and marketing. There are also special research institutes engaged in both basic and applied research in marketing, such as the Norwegian Fund for Market and Distribution Research in Oslo.

Most research projects or programs are fully or mostly government funded. This seems to have contributed to a research bias in the direction of macromarketing and public policy issues. The situation is similar in other European countries, as can be seen in many of the papers presented at two recent cross-Atlantic research colloquia (Fisk et al. 1978).

The review of the research which follows below is organized by institutional analysis of marketing systems and interorganizational relations, consumer behavior and consumer affairs, retailing, and international marketing and foreign trade.

\section{Institutional Analysis of Marketing Systems and Interorganizational Relations}

To abstract, institutions refer to the set of conditions and rules for transactions in society - the rationality context of political-economic behavior. Institutionalism deals with how society is organized to integrate and merge wants and to translate them into solutions (Hernes 1978). A mission of institutional analysis in the social sciences is to address the reciprocal and interactive relationships between institutions and their environment and between institutions and individual actors.

So far, institutional analysis has been applied mainly to study economic and behavioral aspects of distribution channels. A prominent example of the theoretically ambitious work in this area is Reve's (1980) Ph.D. study of the political economy of vertical relationships, having 99 connected wholesaler-retailer dyads as the sample. He found the variables joint programs and formalization of distribution activities to be positively related to cooperative channel sentiments. On the other hand, centralization was negatively related to such sentiments.

Reve has also been in charge of a study using and extending interorganizational theory to investigate purchasing procedures in the offshore oil industry (Johansen 1981). Østerholt and Pedersen (1980) made an in-depth study of the economics of the Norwegian meat industry from cattle raisers to consumers, and traced the intricate patterns of conflict and cooperation at different levels among private firms and producer cooperatives. In another study Øgaard (1981) mapped the role and functions of agents in the distribution system, with particular 
Copyright of Journal of Marketing is the property of American Marketing Association and its content may not be copied or emailed to multiple sites or posted to a listserv without the copyright holder's express written permission. However, users may print, download, or email articles for individual use. 